\title{
PENGGUNAAN KAOLIN SEBAGAI BAHAN PENGISI KOMPON LATEKS UNTUK PELAPIS KAIN INTERLINING
}

\section{USE OF KAOLIN AS A COMPONENT LATEX FILLER FOR INTERLINING FABRIC COATING}

\author{
Luftinor \\ Balai Riset dan Standardisasi Industri Palembang \\ Jl Perindustrian II No. 12 Km 9 Palembang e-mail : luftinor@yahoo.co.id
}

Diterima: 28 Mei 2018; Direvisi: 30 Mei 2018- 22 Juni 2018; Disetujui: 28 Juni 2018

\begin{abstract}
Abstrak
Telah dilakukan penelitian pembuatan kompon lateks alam cair sebagai bahan pelapis pada pembuatan kain keras interlining dengan memvariasikan kehalusan kaolin 100 mesh, 250 mesh dan 400 mesh sebagai bahan pengisi ditambah bahan kimia lain. Tujuan penelitian adalah untuk mendapatkan formula kompon lateks alam cair yang tepat sebagai bahan pelapis dalam pembuatan kain interlining yang mempunyai spesifikasi sesuai dengan standar SNI 0894-2008 Kain Keras (Interlining). Kain interlining adalah kain yang digunakan untuk melapisi bagian-bagian tertentu pada pakaian seperti kerah, pinggang, tempat kancing, ujung lengan, pundak jas dan bagian-bagian lain yang memerlukan kekakuan tinggi serta bentuk yang stabil guna memperindah kenampakan pakaian. Penelitian dilakukan dengan memvariasikan kehalusan bahan pengisi kaolin dalam 3 perlakuan masing-masing 100 mesh, 250 mesh dan 400 mesh serta memvariasikan jumlah bahan pengisi kaolin dalam 4 perlakuan masing-masing $90 \mathrm{~g}, 180 \mathrm{~g}, 270 \mathrm{~g}$ dan $360 \mathrm{~g}$. Parameter yang diuji berupa kekakuan kain, daya rekat, kekuatan tarik, mulur dan kekuatan sobek kain. Bertambahnya kehalusan bahan pengisi kaolin dari 100 mesh ke 400 mesh pada kompon lateks sebagai bahan pelapis, maka kekakuan kain, daya rekat, kekuatan tarik, mulur dan kekuatan sobek kain cenderung meningkat. Sedangkan dengan bertambahnya jumlah penggunaan bahan pengisi kaolin dari $90 \mathrm{~g}$ sampai $270 \mathrm{~g}$ sebagai bahan pelapis dapat meningkatkan kakakuan kain, tetapi penambahan selanjutnya menurunkan kekakuan kain. Sebaliknya penambahan berat bahan pengisi dari $90 \mathrm{~g}$ sampai $360 \mathrm{~g}$ menurunkan daya rekat, kekuatan tarik, mulur dan kekuatan sobek kain. Hasil terbaik dan memenuhi persyaratan SNI 0894-2008 diperoleh pada formula IX menggunakan bahan pengisi kaolin $90 \mathrm{~g}$ dan kehalusan kaolin 400 mesh dengan nilai kekakuan kain $86,2 \mathrm{mg} . \mathrm{cm}$, daya rekat $1,8 \mathrm{~kg} / \mathrm{cm}$, kekuatan tarik 40,59 $\mathrm{kg}$ untuk arah lusi dan $31,43 \mathrm{~kg}$ untuk arah pakan, mulur $41,64 \%$ untuk arah lusi dan $36,63 \%$ untuk arah pakan , kekuatan sobek $7,12 \mathrm{~kg}$ untuk arah lusi dan $6,53 \mathrm{~kg}$ untuk arah pakan.
\end{abstract}

Kata kunci : kaolin, kerah, pengisi, interlining

\section{Abstract}

A study of the manufacture of natural latex liquid compound as a coating material on the manufacture of hard interlining fabric by varying the fineness of kaolin 100 mesh, 250 mesh and 400 mesh as a filler material plus other chemicals. The purpose of this research is to get the right natural liquid latex compound formula as a coating material in the manufacture of interlining fabrics that have specifications in accordance with the SNI 0894-2008 Standard of Hard Cloth (Interlining). Interlining fabrics are fabrics used to coat certain parts of clothing such as collars, waist, buttons, sleeves, shoulders and other parts that require high stiffness and a stable shape to enhance the appearance of clothing. The study was conducted by varying the fineness of the kaolin filler in 3 treatments each 100 mesh, 250 mesh and 400 mesh and varying the amount of kaolin filler in 4 treatments each $90 \mathrm{~g}, 180 \mathrm{~g}, 270 \mathrm{~g}$ and $360 \mathrm{~g}$. The parameters tested were fabric rigidity, adhesive power, tensile strength, elongation and tear strength of fabric. Increased fineness of a kaolin filler from 100 mesh to 400 mesh in latex compound as a coating material, the fabric rigidity, adhesion, tensile strength, elongation and tear strength of the fabric tend to increase. Whereas the increasing amount of kaolin filler usage from $90 \mathrm{~g}$ to $270 \mathrm{~g}$ as a coating material can increase the fabric rag, but the subsequent addition decreases fabric rigidity. Conversely, the weight gain of fillers from $90 \mathrm{~g}$ to $360 \mathrm{~g}$ decreases the adhesiveness, tensile strength, elongation and tear strength of the fabric. The best results and fulfill the requirements of SNI 0894-2008 were obtained on formula IX using a $90 \mathrm{~g}$ kaolin filler and kaolin 400 mesh fineness with fabric stiffness value of $86.2 \mathrm{mg} . \mathrm{cm}$, adhesion $1,8 \mathrm{~kg} / \mathrm{cm}$, tensile strength $40,59 \mathrm{~kg}$ for direction of warp and $31,43 \mathrm{~kg}$ for feed direction, $41.64 \%$ for luran direction and $36,63 \%$ for feed direction, tear strength 7,12 $\mathrm{kg}$ for warp and 6,53 $\mathrm{kg}$ for feed direction.

Keywords : kaolin, collar, filler, interlining

\section{PENDAHULUAN}

Dalam produksi pakaian jadi, disamping diperlukan bahan baku kain juga diperlukan bahan-bahan pembantu, antara lain kain Interlining, disebut juga kain keras atau kain lapis. Kain interlining adalah kain yang digunakan untuk 
melapisi bagian-bagian tertentu pada pakaian seperti kerah, pinggang, tempat kancing, ujung lengan, pundak jas dan bagian-bagian lain yang memerlukan kekakuan tinggi serta bentuk yang stabil guna memperindah kenampakan pakaian (Jeong, et al, 2013)

Pemilihan bahan pelapis dalam proses pelapisan kain interlining sangat penting, karena sifat-sifat kimia dan fisika dari bahan pelapis akan menentukan kualitas pelapisan yang dihasilkan. Bahan yang sudah biasa digunakan untuk pelapis kain interlining ada beberapa jenis bahan sintetis, seperti melamin formaldehyde, urea formaldehyde, polyakrilat dan kapolimer vinil asetat (Suparman, et al, 2009).

Karet alam adalah cairan getah dari tumbuhan Hevea brasiliensis yang merupakan polimer alam dengan monomer isoprena. Polimer karet alam ini terdiri dari $97 \%$ polimer cis-1,4 polyisoprene (Ellul dan Hazelton,1998). Lateks didefinisikan sebagai suatu dispersi yang stabil dari substansi polimer, yaitu polimer karet dalam cairan serum yang berisi berbagai macam senyawa organic dan anorganik (Blackley, 2011) Sedangkan menurut Morton (2008), lateks alam mengandung karet yang merupakan makromolekul poliisoprena (C5H8)n dengan $n$ berkisar antara 3.000 sampai 15.000.

Bahan pengisi biasanya digunakan untuk meningkatkan sifat-sifat mekanikal dari vulkanisat karet alam seperti kekuatan tarik (tensile strength), ketahanan terhadap pengikisan dan pengoyakan (resistances to abrasion and tearing), kekerasan atau untuk memurahkan ongkos suatu produk karet (Eqwaikhide, et al, 2008). Bahan pengisi juga mempengaruhi sifat-sifat viskoelastis (viscoelastic properties) dan kekuatan kompon karet. Menurut William (2008) berdasarkan efek penguatan terhadap sifat-sifat karet (rubber properties), maka bahan pengisi dapat dikelompokkan menjadi 3 yaitu penguat (reinforcing), semi penguat dan bukan penguat (non reinforcing). Pengisi penguat (reinforcing filler) digunakan untuk meningkatkan sifatsifat mekanikal vulkanisat karet alam seperti yang telah dijelaskan diatas.
Pengisi bukan penguat dipakai untuk memurahkan ongkos produksi dan memudahkan dalam proses. Pengisi bukan penguat juga dapat menyebabkan peningkatan kekerasan, penurunan kekuatan tarik dan kekuatan sobek, resistansi pengikisan, dan resiliensi dari vulkanisat karet. Kaolin, Kalsium karbonat $\left(\mathrm{CaCO}_{3}\right)$ dan barium sulfat adalah contohcontoh bahan pengisi bukan penguat karet (Yudha, et al, 2013)

Kaolin merupakan masa batuan yang tersusun dari material lempung yang berwarna putih atau agak keputihan Menurut Ridla, et al (2008), kaolin mempunyai komposisi hidrous aluminium silikat $\left(2 \mathrm{H}_{2} \mathrm{OAl}_{2} \mathrm{O}_{3} 2 \mathrm{SiO}_{2}\right)$ dan mineral lainnya. Komposisi mineral yang termasuk kedalam kaolin antara lain kaolinit, nakrit dan halloysit (mineral utama $\mathrm{Al}_{2}(\mathrm{OH})_{4} \mathrm{SiO}_{5} 2 \mathrm{H}_{2} \mathrm{O}$ ). Sifat fisik kaolin lainnya seperti kekerasan antara 2-2,5 (skala Mohs), berat jenis 2,60-2,63, daya hantar panas dan listrik rendah serta kadar asam $(\mathrm{pH})$ yang bervariasi. Kaolin biasanya digunakan sebagai bahan baku industri baik sebagai bahan utama maupun bahan pembantu (Mustafa, 2012). Pada industri karet kaolin digunakan sebagai bahan tambahan yang berfungsi sebagai bahan pengisi untuk menambah volume dan meningkatkan kekerasan (Dewantara, 2015).

Dalam proses pembuatan barang jadi karet, terlebih dahulu cairan lateks pekat harus dibuat jadi kompon lateks. Kompon lateks adalah lateks pekat yang ditambah dengan berbagai bahan kimia untuk memberikan sifat barang jadi karet yang diinginkan (Barney, 2003).

Produk-produk yang dihasilkan dari lateks karet alam antara lain seperti sarung tangan, benang karet, balon keteter, peralatan kesehatan, pembalut luka elastis, kondom, tiup stateskop dan lain-lain (Richard, 2009).

Teknologi pembuatan kain interlining yang berkembang di Indonesia adalah teknologi penyempurnaan konvensional, yaitu kain direndam dalam larutan zat-zat tertentu, diperas kemudian dipanaskan, dicuci dan dikeringkan. Proses tersebut memerlukan serangkaian mesin-mesin besar yang harganya cukup mahal, sehingga kain interlining pada umumnya 
diproduksi oleh pabrik tekstil dengan modal investasi yang cukup besar (Sulam, 2008)

Pada penelitian terdahulu telah dilakukan pembuatan kain interlining menggunakan lateks alam sebagai bahan pelapis dengan memvariasikan berat bahan pengisi kaolin dan suhu pada proses vulkanisasi/pengeringan dengan hasil yang cukup baik (Luftinor, 2017)

Selanjutnya pada penelitian ini dicoba memvariasikan kehalusan kaolin sebagai bahan pengisi kompon lateks alam cair ditambahkan bahan-bahan kimia lain yang berfungsi untuk mendapatkan sifat fisika kain interlining seperti kekakuan, kekuatan tarik, ketahanan sobek yang lebih baik.

Selain mengurangi subsidi impor, penggunaan lateks alam cair dan bahan pengisi kaolin dapat dilakukan dengan teknologi dan peralatan yang sederhana serta biaya yang lebih murah sehingga dapat diterapkan oleh industry kecil (IKM).

Tujuan penelitian untuk mendapatkan formula yang tepat penggunaan lateks alam cair dan kehalusan bahan pengisi kaolin serta bahan pembantu lainnya sebagai bahan pelapis pada pembuatan kain interlining

\section{BAHAN DAN METODE}

\section{Bahan}

Bahan-bahan yang digunakan dalam penelitian ini terdiri dari bahan baku lateks alam hasil sentrifugasi dengan spesifikasi kadar jumlah padatan $61,25 \%$, kadar karet kering $60,43 \%$, kadar amoniak $0,68 \%$ dan kadar koagulum $0,039 \%$, kain kapas dengan konstruksi anyaman plat, tetal lusi 96 helai/inch, tetal pakan 80 helai/inch, nomor benang lusi Ne1 42, nomor benang pakan Ne1 30 dan bahan pembantu terdiri dari bahan penggiat $\mathrm{ZnO}$, antioksidan lonol, bahan pengisi Kaolin, bahan pencepat Zinc diethyldithiocarbamate (ZDEC) dan Zinc 2-mercaptobenzothiazol (ZMBT), bahan pemvulkanisasi sulfur dan bahan penstabil $\mathrm{KOH}$.

\section{Peralatan}

Peralatan yang digunakan terdiri dari penggiling kaolin, ayakan, pemutar guci (ball mill), mesin pengaduk (mixer), Screen dan rakel, oven pengering, alat uji kekakuan kain, daya rekat, kekuatan tarik dan kekuatan sobek.

\section{Metoda Penelitian}

Penelitian ini dilaksanakan di Laboratorium Balai Riset dan Standardisasi Industri Palembang, mempelajari hubungan antara faktor kehalusan bahan pengisi kaolin dan faktor berat bahan pengisi kaolin terhadap kekakuan, daya rekat, kekuatan tarik, mulur dan kekuatan sobek kain interlining.

Tabel 1. Formula Kompon Lateks Pelapis Kain Interlining

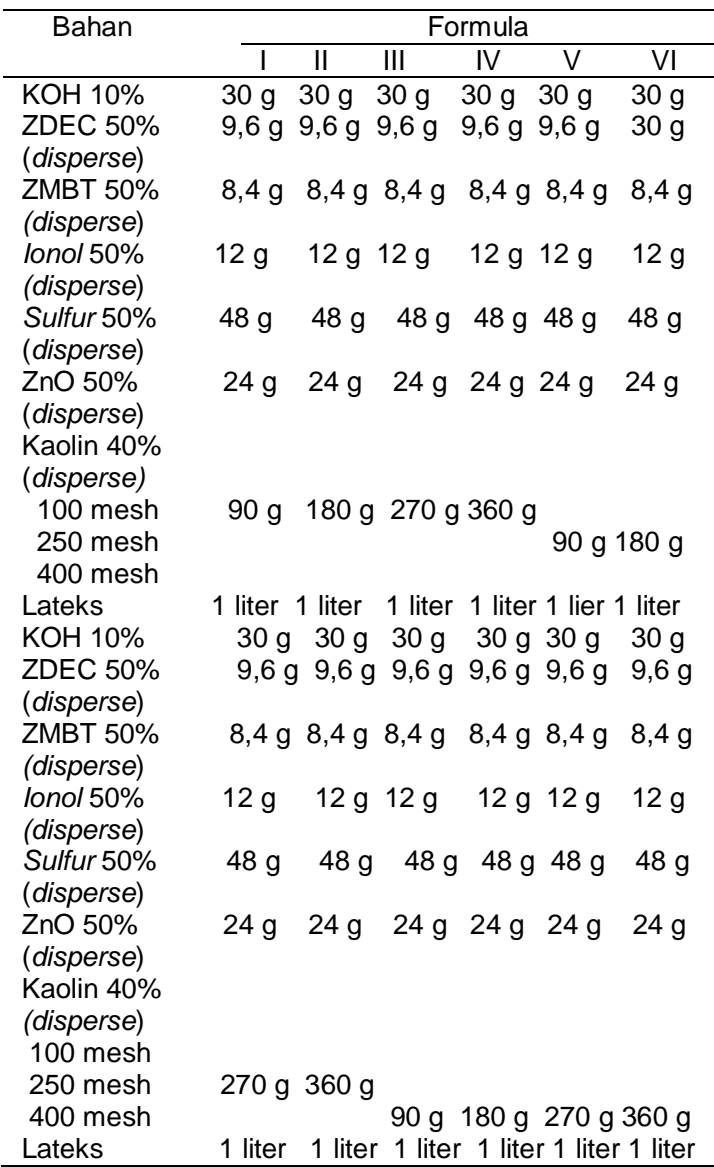

Dalam penelitian dilakukan percobaan pembuatan 12 formula kompon lateks dengan memvariasikan kehalusan bahan pengisi kaolin ukuran 100 mesh, 250 mesh dan 400 mesh dan memvariasikan berat bahan pengisi kaolin, yaitu $90 \mathrm{~g}, 180$ $\mathrm{g}, 270 \mathrm{~g}$ dan $360 \mathrm{~g}$ seperti dapat dilihat pada Tabel 1.

\section{Penggilingan dan pengayakan kaolin}


Bahan pengisi kaolin dilakukan penggilingan dan pengayakan sesuai dengan kehalusan yaitu 100 mesh, 250 mesh dan 400 mesh

\section{Pembuatan Kompon Lateks}

Diagram alir tahapan proses pembuatan kain interlining seperti dapat dilihat pada Gambar 1.

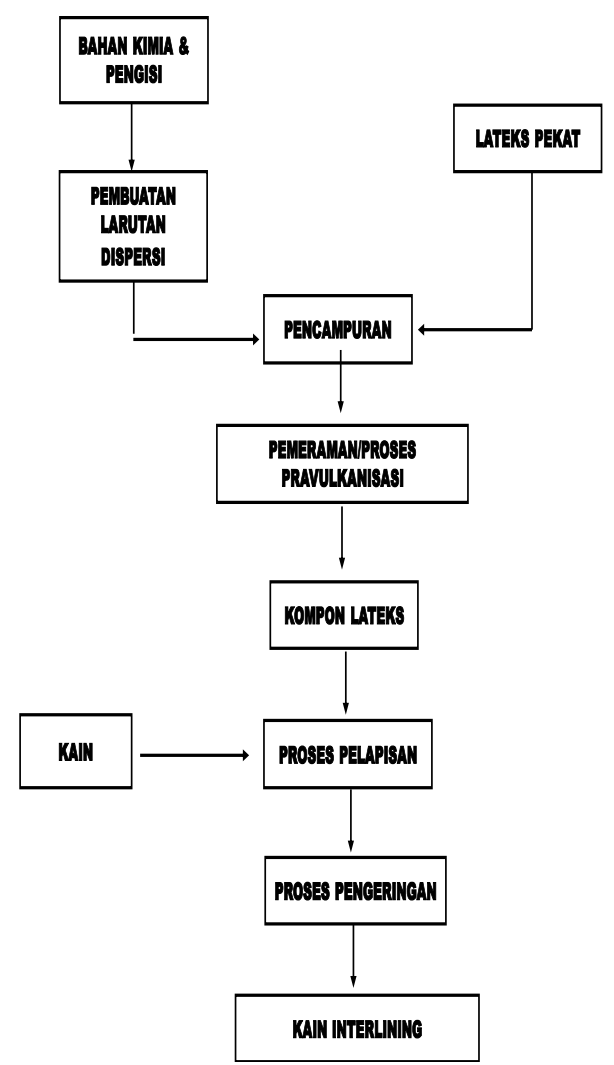

Gambar 1. Urutan pembuatan kain interlining

Bahan-bahan kimia seperti ZDEC, ZMBT, lonol, ZnO, Sulfur dan bahan pengisi kaolin masing-masing dibuat larutan dispersi dengan cara ditimbang sesuai dengan formula, kemudian dimasukkan kedalam guci dilengkapi dengan butiran peluru. Guci ditutup rapat dan diputar dalam alat ball mill selama 24 jam

Bahan-bahan kimia hasil dispersi dicampur dengan lateks pekat yang telah disentrifugasi sesuai dengan formula seperti dapat dilihat pada Tabel 1 ditambah dengan $\mathrm{KOH}$ pada mesin mixer diaduk selama 30 menit. Selanjutnya didiamkan selama 24 jam agar campuran lebih homogen dan terbentuk kompon lateks.

Proses pelapisan kompon lateks menggunakan alat screen dan rakel sesuai dengan ukuran sampel, bahan pelapis diratakan ke seluruh permukaan kain

\section{Proses pengeringan}

Kain yang telah dilapisi kompon lateks selanjutnya dikeringkan dalam oven pada suhu $120^{\circ} \mathrm{C}$ selama 15 menit.

\section{Parameter yang Diuji}

Berupa kekakuan kain, daya rekat, kekuatan tarik kain arah lusi dan arah pakan, mulur kain arah lusi dan arah pakan dan kekuatan sobek kain arah lusi dan arah pakan.

\section{HASIL DAN PEMBAHASAN}

\section{A. Kekakuan Kain}

Salah satu sifat fisika kain interlining yang sangat penting dan perlu dilakukan pengujian adalah kekakuan kain yang menggambarkan sifat kekerasan kain dinyatakan dalam mg.cm. Hasil pengujian terhadap kekakuan kain seperti dapat dilihat pada histogram Gambar 2, kekakuan kain cenderung meningkat dengan bertambahnya kehalusan bahan pengisi/filler kaolin dan bertambahnya penggunaan bahan pengisi kaolin pada proses pembuatan kompon lateks.

Penggunaan bahan pengisi kaolin pada pembuatan kompon lateks formula III dengan kehalusan kaolin 100 mesh berat $270 \mathrm{~g}$ memberikan nilai kekakuan 85,5 mg.cm, sedangkan pada formula VII dengan kehalusan kaolin 250 mesh berat $270 \mathrm{~g}$ nilai kekakuan kain meningkat menjadi 90,6 mg.cm seperti terlihat pada histogram Gambar 2. demikian juga pada formula XI kekakuan kain meningkat lagi menjadi 97,6 mg.cm yang merupakan nilai kekakuan kain tertinggi.

Selanjutnya dengan meningkatnya penggunaan berat bahan pengisi kaolin sampai pada batas tertentu juga akan meningkatkan kekakuan kain interlining, seperti juga terlihat pada histogram Gambar 2. Berat bahan pengisi kaolin 90 g kehalusan 400 mesh pada formula IX memberikan nilai kekakuan kain 86,2 
mg.cm, sedangkan berat bahan pengisi kaolin $180 \mathrm{~g}$ kehalusan 400 mesh pada formula $X$ nilai kekakuan kain meningkat menjadi 92,8 mg.cm, selanjutnya pada formula XI meningkat lagi menjadi 97,6 mg.cm yang merupakan kekakuan tertinggi. Sedangkan pada pada formula XII berat bahan pengisi kaolin $360 \mathrm{~g}$ kehalusan 400 mesh kekakuan kain menurun menjadi $96,9 \mathrm{mg} . \mathrm{cm}$

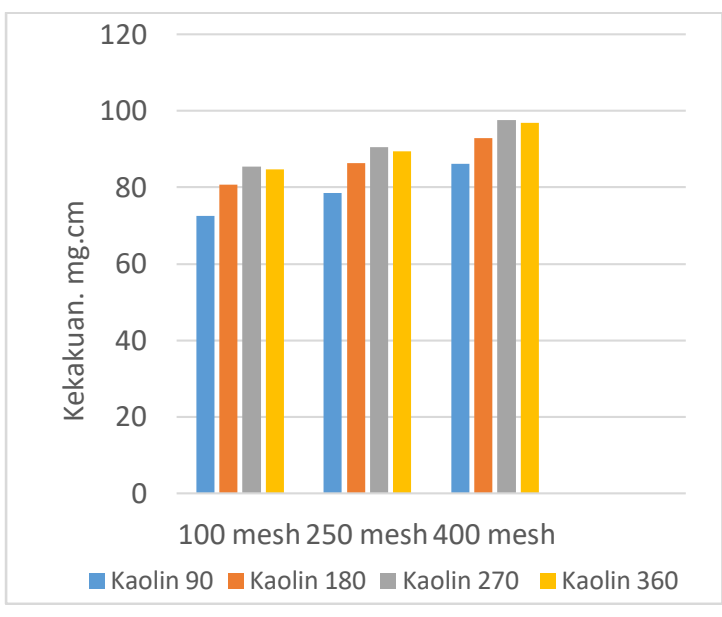

Gambar 2.Histogram Kekakuan Kain

Dalam struktur rantai polimer Kaolin berbentuk benda padat dan merupakan bahan pengisi tidak aktif memiliki komposisi utama berupa hidrous alumunium silikat $\left(\mathrm{Al}_{2} \mathrm{O}_{3} \cdot 2 \mathrm{SiO}_{2} \cdot 2 \mathrm{H}_{2} \mathrm{O}\right)$ dan beberapa mineral (Sitorus, et al, 2013). Jika ditambahkan kedalam campuran lateks karet alam, kaolin akan menambahkan kekerasan dan kekakuan (Fachry, et al., 2012) dan (Luftinor, 2017)

Menurut Mishra and Shimpi (2005) Penambahan bahan pengisi kedalam karet mengubah sifat fisisnya secara signifikaan, secara umum akan terjadi penambahan sifat, seperti sifat mekanik dan sifat thermal. Kekakuan dipengaruhi oleh jumlah, ukuran partikel, keadaan permukaan dan kerataan penyebaran bahan pengisi (Abednego, 1998), semakin halus bahan pengisi yang digunakan, dan semakin banyak jumlah bahan pengisi, kekakuan kain akan semakin meningkat. Semakin halus bahan pengisi akan menyebabkan dispersi dan homogenitas bahan pengisi lebih merata, sehingga dalam proses vulkanisasi kompon lateks akan lebih baik (Al Musawi, et al, 2008), dengan demikian dan ikatan kimia antara kompon lateks dan bahan kain akan semakin kuat dan dapat menutupi permukaan kain lebih sempurna Jika jumlah bahan pengisi kaolin yang digunakan terlalu dominan atau sudah melampaui batas tertentu akan memperlambat proses vulkanisasi dan mengurangi kematangan kompon lateks.

(Fachry, et al., 2012) dan (Indiah dan Herminiwati, 2014), menyebabkan kekakuan kain interlining yang dihasilkan semakin berkurang,

Nilai kekakuan kain interlining maksimum 97,6 mg.cm.seperti terlihat pada histogram Gambar 3. diperoleh pada kompon XI menggunakan kaolin berat 270 $\mathrm{g}$ dan kehalusan 400 mesh

\section{B. Daya Rekat}

Daya rekat dapat menggambarkan daya tahan produk hasil pelapisan selama pemakaian.dan juga menggambarkan kecocokan antara bahan kompon lateks dengan bahan kain yang digunakan atau daya adhesi dan kohesi dinyatakan dalam $\mathrm{kg} / \mathrm{cm}$.

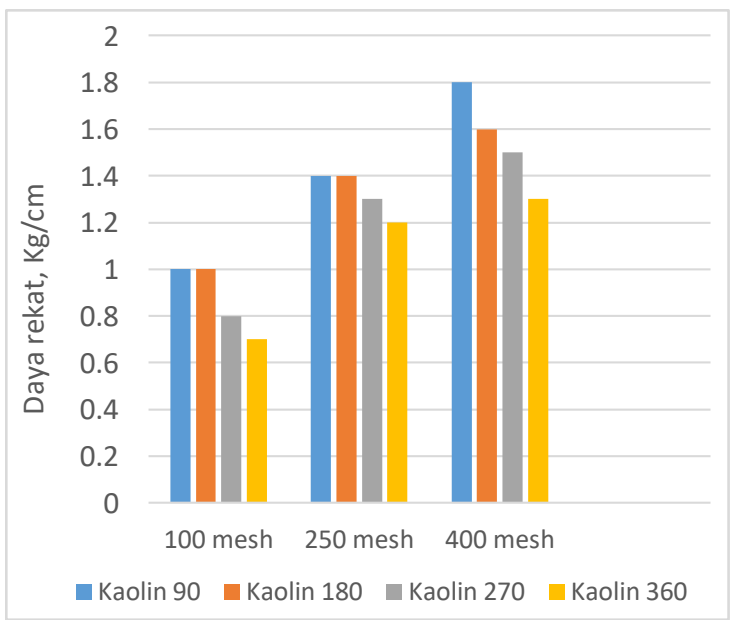

Gambar 3. Histogram Daya rekat

Hasil pengujian terhadap daya rekat seperti dapat dilihat pada histogram Gambar 3, daya rekat cenderung meningkat dengan bertambahnya kehalusan bahan pengisi kaolin dan cenderung menurun dengan bertambahnya penggunaan bahan pengisi kaolin dalam campuran kompon lateks

Penggunaan bahan pengisi kaolin pada pembuatan kompon lateks formula I dengan kehalusan kaolin 100 mesh berat 
$90 \mathrm{~g}$ memberikan nilai daya rekat 1,0 $\mathrm{kg} / \mathrm{cm}$ sedangkan pada formula $\mathrm{V}$ dengan kehalusan kaolin 250 mesh berat $90 \mathrm{~g}$ nilai daya rekat meningkat menjadi 1,4 $\mathrm{kg} / \mathrm{cm}$ seperti terlihat pada histogram Gambar 4, demikian juga pada formula IX daya rekat meningkat lagi menjadi 1,8 $\mathrm{kg} / \mathrm{cm}$ yang merupakan nilai daya rekat kain tertinggi.

Meningkatnya nilai daya rekat antara kompon lateks dengan bahan kain ada hubungannya dengan molekul isoprena pada kompon lateks yang mengadakan ikatan dengan serat pada kain, semakin halus bahan pengisi kaolin yang digunakan pada kompon lateks maka molekul isoprene pada kompon lateks yang terserap dan mengadakan ikatan dengan serat pada kain akan semakin banyak dan kuat sehingga daya rekatnya semakin tinggi. (Herminiwati dan Arum, 2010)

Sebaliknya dengan meningkatnya penggunaan berat bahan pengisi kaolin akan menurunkan daya rekat kain interlining, seperti juga terlihat pada histogram Gambar 3. Berat bahan pengisi kaolin $90 \mathrm{~g}$ kehalusan 400 mesh pada formula IX memberikan daya rekat 1,8 $\mathrm{kg} / \mathrm{cm}$, sedangkan berat bahan pengisi kaolin $180 \mathrm{~g}$ kehalusan 400 mesh pada formula $X$ nilai daya rekat menurun menjadi $1,6 \mathrm{~kg} / \mathrm{cm}$, selanjutnya pada formula XI dan XII daya rekat menurun lagi menjadi 1,5 dan $1,3 \mathrm{~kg} / \mathrm{cm}$.

Menurunnya nilai daya rekat antara kompon lateks dan kain dengan bertambahnya penggunaan bahan pengisi kaolin disebabkan oleh semakin berkurangnya jumlah molekul-molekul isoprena pada kompon lateks yang mengadakan ikatan dengan serat pada kain.

Nilai daya rekat kain interlining maksimum 1,8 kg/cm .seperti terlihat pada histogram Gambar 4. diperoleh pada kompon IX menggunakan kaolin berat 90 $\mathrm{g}$ dan kehalusan 400 mesh.

\section{Kekuatan Tarik}

Kekuatan tarik merupakan tenaga yang dibutuhkan untuk menarik bahan kain sampai putus dan merupakan pengujian fisika kain yang cukup penting dan sering dilakukan dinyatakan dalam $\mathrm{kg}$.
Hasil pengujian sifat fisika kain interlining terhadap kekuatan tarik seperti terlihat pada histogram Gambar 4 dan Gambar 5, Kekuatan tarik kain interlining cenderung meningkat dengan bertambahnya kehalusan bahan pengisi kaolin dan cenderung menurun dengan bertambahnya berat bahan pengisi kaolin pada kompon lateks baik kekuatan tarik arah lusi maupun kekuatan tarik arah arah pakan.

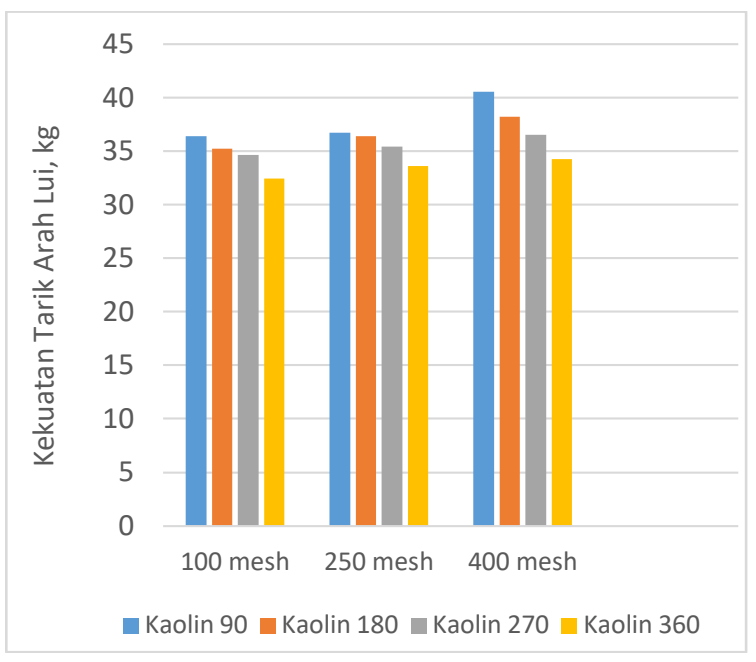

Gambar 4. Histogram Kekuatan Tarik Arah Lusi

Histogram Gambar 4 dapat dilihat bahwa penggunaan bahan pengisi kaolin pada pembuatan kompon lateks formula I dengan kehalusan kaolin 100 mesh berat $90 \mathrm{~g}$ memberikan nilai kekuatan tarik arah lusi $36,43 \mathrm{~kg}$, sedangkan pada formula $V$ dengan kehalusan kaolin 250 mesh berat $90 \mathrm{~g}$ nilai kekuatan tarik meningkat menjadi $36,72 \mathrm{~kg}$, demikian juga pada formula IX kekuatan tarik meningkat lagi menjadi 40,59 kg yang merupakan nilai kekuatan tarik kain tertinggi.arah lusi.

Histogram Gambar 5 dapat dilihat bahwa penggunaan bahan pengisi kaolin pada pembuatan kompon lateks formula I dengan kehalusan kaolin 100 mesh berat $90 \mathrm{~g}$ memberikan nilai kekuatan tarik arah pakan $28,72 \mathrm{~kg}$, sedangkan pada formula $\mathrm{V}$ dengan kehalusan kaolin 250 mesh berat $90 \mathrm{~g}$ nilai kekuatan tarik meningkat menjadi 29,54 kg, demikian juga pada formula IX kekuatan tarik meningkat lagi 


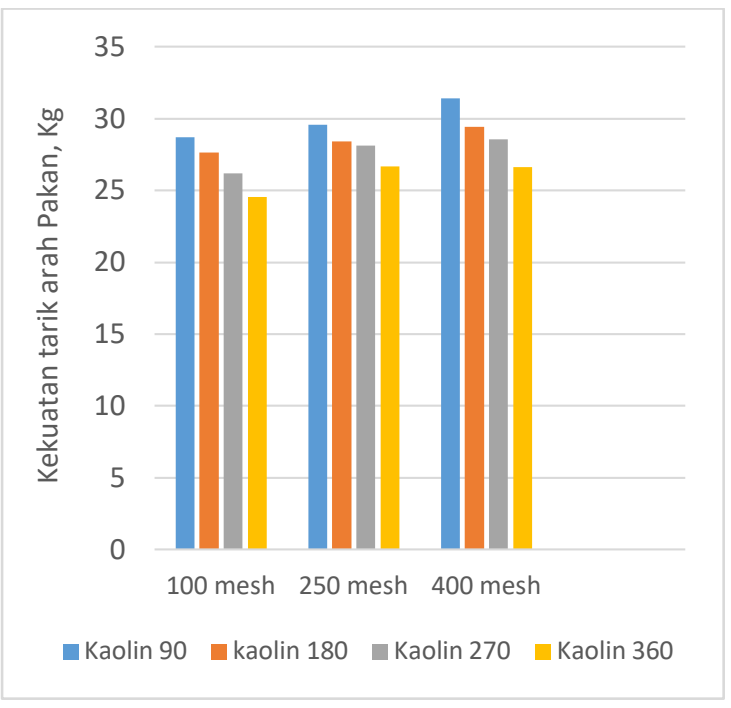

Gambar 5. Histogram Kekuatan Tarik Arah Pakan

menjadi $31,43 \mathrm{~kg}$ yang merupakan nilai kekuatan tarik kain tertinggi.arah pakan

Semakin kecil atau halus ukuran partikel bahan pengisi dapat memberikan sifat kekuatan tarik yang lebih besar karena dapat meningkatkan jumlah interaksi antara lateks dan dan bahan pengisi (Ahmed, et al., 2012 dan Arun, et al., 2010)

Sebaliknya dengan meningkatnya penggunaan berat bahan pengisi kaolin akan menurunkan kekuatan tarik kain interlining, seperti terlihat pada histogram Gambar 4. Berat bahan pengisi kaolin 90 $\mathrm{g}$ kehalusan 400 mesh pada formula IX memberikan kekuatan tarik arah lusi 40, $59 \mathrm{~kg}$, sedangkan berat bahan pengisi kaolin $180 \mathrm{~g}$ kehalusan 400 mesh pada formula $X$ nilai kekuatan tarik menurun menjadi $38,25 \mathrm{~kg}$, selanjutnya pada formula XI dan XII kekuatan tarik kain interlining arah lusi menurun lagi menjadi $36,52 \mathrm{~kg}$ dan $34,25 \mathrm{~kg}$. Kekuatan tarik kain interlining arah pakan seperti terlihat pada histogram Gambar 5, penggunaan bahan pengisi kaolin pada pembuatan kompon lateks formula IX berat bahan pengisi kaolin $90 \mathrm{~g}$ kehalusan 400 mesh memberikan nilai kekuatan tarik arah pakan 31,43 , sedangkan pada formula $X$ berat bahan pengisi $180 \mathrm{~g}$ kehalusan 400 mesh nilai kekuatan tarik menurun menjadi 29,46 kg, selanjutnya pada formula XI dan XII kekuatan tarik kain interlining arah lusi menurun lagi menjadi $28,55 \mathrm{~kg}$ dan 26,65 $\mathrm{kg}$.

Menurunnya nilai kekuatan tarik dengan bertambahnya penggunaan bahan pengisi kaolin disebabkan oleh bahan kaolin merupakan bahan pengisi bukan aktif sehingga dengan bertambahnya penggunaan bahan pengisi kaolin dalam kompon lateks maka ikatan silang yang terjadi antara lateks dengan bahan pengisi semakin lemah sehingga kekuatan tarik juga semakin menurun, .(Chuayjuljit, et al, 2012, Nuraya, et al, 2012)

\section{Mulur}

Mulur adalah penambahan panjang sejalan dengan kekuatan tarik merupakan tenaga yang dibutuhkan untuk menarik bahan kain interlining sampai putus dinyatakan dengan \% dari panjang potongan uji sebelum diregangkan dan merupakan pengujian fisika kain interlining yang cukup penting dan sering dilakukan disamping kekakuan dan kekuatan tarik

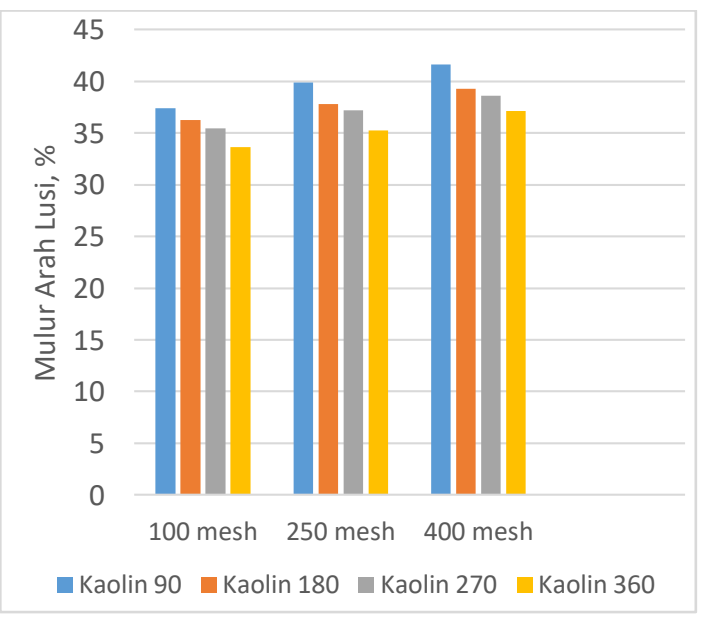

Gambar 6. Histogram Mulur Arah Lusi

Hasil pengujian sifat fisika kain interlining terhadap mulur seperti terlihat pada histogram Gambar 6 dan Gambar 7, Mulur cenderung meningkat dengan bertambahnya kehalusan bahan pengisi kaolin dan menurun dengan bertambahnya penggunaan bahan pengisi kaolin, baik mulur arah lusi maupun mulur arah arah pakan.

Histogram Gambar 6. dapat dilihat bahwa penggunaan bahan pengisi kaolin pada pembuatan kompon lateks formula I 
dengan kehalusan kaolin 100 mesh berat $90 \mathrm{~g}$ memberikan nilai mulur arah lusi $37,43 \%$, sedangkan pada formula $\mathrm{V}$ dengan kehalusan kaolin 250 mesh berat $90 \mathrm{~g}$ nilai mulur meningkat menjadi $39,91 \%$, demikian juga pada formula IX nilai mulur meningkat lagi menjadi $41,64 \%$ yang merupakan nilai mulur kain tertinggi.arah lusi.

Histogram Gambar 7. dapat dilihat bahwa penggunaan bahan pengisi kaolin pada pembuatan kompon lateks formula I dengan kehalusan kaolin 100 mesh berat $90 \mathrm{~g}$ memberikan nilai mulur kain arah pakan 33,76\%, sedangkan pada formula $\mathrm{V}$ dengan kehalusan kaolin 250 mesh berat $90 \mathrm{~g}$ nilai mulur kain meningkat menjadi $34,78 \%$ demikian juga pada formula IX nilai mulur kain meningkat lagi menjadi $36,63 \%$ yang merupakan nilai mulur kain tertinggi.arah pakan.

Kehalusan bahan pengisi mempengaruhi intensitas rantai polimer yang teradsorbsi, sehingga dapat meningkatkan interaksi van der waals antara bahan pengsi dan rantai polimer lateks. Semakin kecil ukuran bahan pengisi semakin besar energi deformasinya sehingga dapat meningkatkan kekuatan tarik dan mulur (Fang, et al., 2014)

Sebaliknya dengan meningkatnya penggunaan berat bahan pengisi kaolin akan menurunkan nilai mulur kain interlining, seperti terlihat pada histogram Gambar 6. Berat bahan pengisi kaolin 90 g kehalusan 400 mesh pada formula IX memberikan nilai mulur arah lusi $41,64 \%$, sedangkan berat bahan pengisi kaolin 180 $\mathrm{g}$ kehalusan 400 mesh pada formula $X$ nilai mulur menurun menjadi $39,25 \%$, selanjutnya pada formula XI dan XII mulur kain interlining arah lusi menurun lagi menjadi $38,61 \%$ dan $37,14 \%$. Mulur kain interlining arah pakan seperti terlihat pada histogram Gambar 7, penggunaan bahan pengisi kaolin pada pembuatan kompon lateks formula IX berat bahan pengisi kaolin $90 \mathrm{~g}$ kehalusan 400 mesh memberikan nilai mulur kain arah pakan $36,63 \%$, sedangkan pada formula $X$ berat bahan pengisi $180 \mathrm{~g}$ kehalusan 400 mesh nilai mulur kain menurun menjadi $36,12 \%$, selanjutnya pada formula XI dan XII nilai mulur kain interlining arah pakan menurun lagi menjadi $34,82 \%$ dan $32,14 \%$.

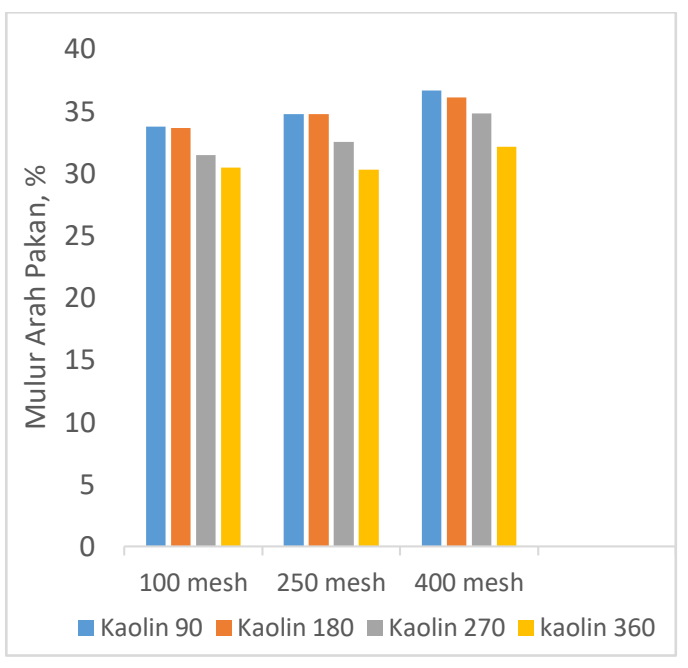

Gambar 7. Histogram Mulur Arah Pakan

Menurunnya sifat mulur kain interlining baik arah lusi maupun arah pakan dengan banyaknya bahan pengisi kaolin yang ditambahkan dalam kompon lateks karet alam disebabkan oleh vulkanisat karet alam tanpa bahan pengisi memiliki nilai mulur atau perpanjangan putus yang lebih tinggi dibanding vulkanisat karet alam dengan tambahan bahan pengisi. (Polmanteer and Lentz, 2008). Bahan pengisi dapat mengurangi kerapatan ikatan silang sehingga memberikan efek kaku terhadap rantai polimer serta dapat menurunkan kekuatan tarik dan mulur (Al-Mosawi, et al., 2008)

\section{E. Kekuatan Sobek}

Kekuatan sobek merupakan tenaga yang dibutuhkan untuk merobek bahan kain interlining dan merupakan pengujian fisika kain interlining yang cukup penting dan sering dilakukan disamping kekuatan tarik dan mulur dinyatakan dalam $\mathrm{kg}$.

Hasil pengujian sifat fisika kain interlining terhadap kekuatan sobek seperti terlihat pada Gambar 8 dan Gambar 9, kekuatan sobek cenderung meningkat dengan bertambahnya kehalusan bahan pengisi kaolin dan cenderung menurun dengan bertambahnya penggunaan bahan pengisi kaolin, baik kekuatan sobek arah lusi maupun kekuatan sobek arah arah pakan. 
Histogram Gambar 8 dapat dilihat bahwa penggunaan bahan pengisi kaolin pada pembuatan kompon lateks formula I dengan kehalusan kaolin 100 mesh berat $90 \mathrm{~g}$ memberikan nilai kekuatan sobek arah lusi $5,83 \mathrm{~kg}$, sedangkan pada formula $\mathrm{V}$ dengan kehalusan kaolin 250 mesh berat $90 \mathrm{~g}$ nilai kekuatan sobek meningkat menjadi $6,25 \mathrm{~kg}$, demikian juga pada formula IX kekuatan sobek meningkat lagi menjadi $7,12 \mathrm{~kg}$ yang merupakan nilai kekuatan sobek kain tertinggi arah lusi.

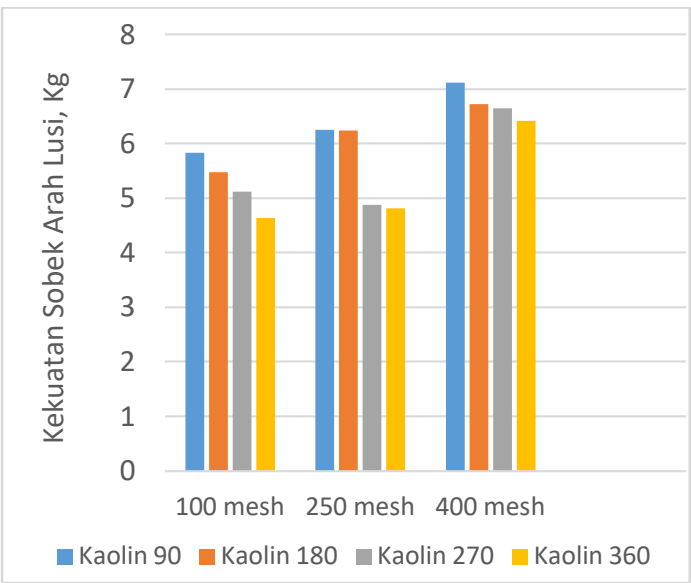

Gambar 8. Histogram Kekuatan Sobek Arah Lusi

Histogram Gambar 9 dapat dilihat bahwa penggunaan bahan pengisi kaolin pada pembuatan kompon lateks formula I dengan kehalusan kaolin 100 mesh berat $90 \mathrm{~g}$ memberikan nilai kekuatan sobek kain arah pakan $5,46 \mathrm{~kg}$, sedangkan pada formula $\mathrm{V}$ dengan kehalusan kaolin 250 mesh berat $90 \mathrm{~g}$ nilai kekuatan sobek kain meningkat menjadi 5,98 kg demikian juga pada formula IX nilai kekuatan sobek kain meningkat lagi menjadi $6,53 \mathrm{~kg}$ yang merupakan nilai kekuatan sobek kain tertinggi.arah pakan. Meningkatnya kekuatan sobek kain interlining baik arah lusi maupun arah pakan dengan semakin halusnya bahan pengisi kaolin yang digunakan disebabkan oleh adanya pertambahan jumlah ikatan silang pada kompon lateks dalam proses vulkanisasi. (Poompradub, et al., 2011). Semakin halus bahan pengisi yang digunakan maka jumlah ikatan silang semakin bertambah, mengakibatkan meningkatnya nilai kekuatan sobek (Sasidharan, et al., 2007).
Sebaliknya dengan meningkatnya penggunaan berat bahan pengisi kaolin akan menurunkan nilai kekuatan sobek kain interlining, seperti terlihat pada histogram Gambar 8. Berat bahan pengisi kaolin $90 \mathrm{~g}$ kehalusan 400 mesh pada formula IX memberikan nilai kekuatan sobek arah lusi $7,12 \mathrm{~kg}$, sedangkan berat bahan pengisi kaolin $180 \mathrm{~g}$ kehalusan 400 mesh pada formula $X$ nilai kekuatan sobek menurun menjadi $6,72 \mathrm{~kg}$, selanjutnya pada formula XI dan XII kekuatan sobek kain interlining arah lusi menurun lagi menjadi $6,65 \mathrm{~kg}$ dan $6,42 \mathrm{~kg}$. Kekuatan sobek kain interlining arah pakan seperti terlihat pada histogram Gambar 9, penggunaan bahan pengisi kaolin pada pembuatan kompon lateks formula IX berat bahan pengisi kaolin $90 \mathrm{~g}$ kehalusan 400 mesh memberikan nilai kekuatan sobek kain arah pakan 6,53 kg, sedangkan pada formula $X$ berat bahan pengisi $180 \mathrm{~g}$ kehalusan 400 mesh nilai kekuatan sobek kain menurun menjadi $6,11 \mathrm{~kg}$, selanjutnya pada formula XI nilai kekuatan sobek kain interlining arah pakan tetap $6,11 \mathrm{~kg}$ dan pada formula XII menurun lagi menjadi $5,54 \mathrm{~kg}$.

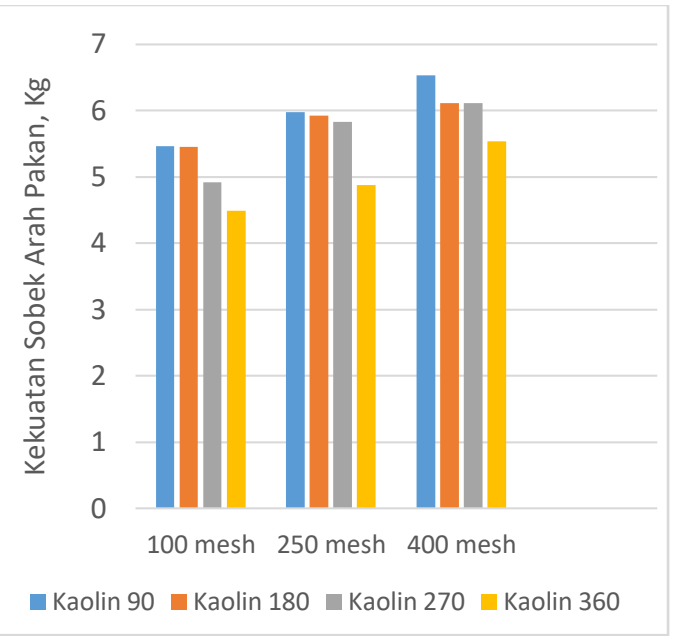

Gambar 9. Histogram Kekuatan Sobek Arah Pakan

Menurunnya kekuatan sobek kain interlining baik arah lusi maupun arah pakan dengan semakin banyaknya bahan pengisi kaolin yang ditambahkan dalam kompon lateks karet alam disebabkan oleh kerapatan ikatan silang dalam vulkanisat karet. Menurut Maged, et al., (2008), Semakin banyak bahan pengisi 
kaolin ditambahkan dalam kompon lateks maka kerapatan ikatan silangnya semakin berkurang dan mengakibatkan nilai kekuatan sobek menurun

\section{KESIMPULAN}

Peningkatan kehalusan kaolin sebagai bahan pengisi kompon lateks ditambah bahan-bahan kimia lain sebagai pelapis pada pembuatan kain interlining dapat meningkatkan sifat fisika kekakuan, daya rekat, kekuatan tarik, mulur dan kuatan sobek kain interlining. Sedangkan peningkatan jumlah bahan pengisi kaolin pada pembuatan kompon lateks sebagai bahan pelapis sampai batas tertentu dapat meningkatkan sifat fisika kekakuan kain interlining tetapi sebaliknya dapat menurunkan sifat fisika daya rekat, kekuatan tarik, mulur dan kekuatan sobek kain interlining. Hasil terbaik dan memenuhi persyaratan SNI 0894-2008 diperoleh pada formula IX menggunakan bahan pengisi kaolin $90 \mathrm{~g}$ dan kehalusan kaolin 400 mesh dengan nilai kekakuan kain $86,2 \mathrm{mg} . \mathrm{cm}$, daya rekat $1,8 \mathrm{~kg} / \mathrm{cm}$, kekuatan Tarik 40,59 kg untuk arah lusi dan $31,43 \mathrm{~kg}$ untuk arah pakan, mulur $41,64 \%$ untuk arah lusi dan $36,63 \%$ untuk arah pakan, kekuatan sobek 7,12 kg untuk arah lusi dan $6,53 \mathrm{~kg}$ untuk arah pakan.

\section{UCAPAN TERIMA KASIH}

Penulis menyampaikan terima kasih kepada Kepala Baristand Industri Palembang, rekan-rekan tim riset, Dewan Redaksi, Mitra Bestari dan Redaksi Pelaksana atas terlaksananya penelitian dan terbitnya tulisan ini.

\section{DAFTAR PUSTAKA}

Abednego, (1998), Bahan Kimia Penyusun kompon, Bogor, Balai Penelitian Teknologi Karet.

Ahmed, K, Nizami, SS, Raza, NZ, and Mahmood, K, (2012), Mechanical, swelling and thermal aging properties of marble sludge natural rubber composite, International Journal of Industrial Chemistry, 3 (1) : 1-12

Al-Mosawi, Al., Ali, MM. Dan Mohammad,JH., (2008), Experimental approach to mechanical properties of natural rubber mixing with calcium carbonate powder, International Journal of physical Sciences, 49 (7), 6280-6292.

Arun, K, J, Francis \& Joseph R (2010), Mechanical properties of NR latex, nano silica, composites, material rapid communication, OAM-RC:4,1520-1525

Barney, JA, (2003), Natural Rubber Production, di dalam Lecture de Notes, Bogor, Balai Penelitian Perkebunan

Blackley, DC (2011), High Polymer Latice, New York, Maclaren and sons Ltd

Chuayjuljit. S, Imvittaya and Nuchanat (2012), Effects of Particle Size and Amount of Carbon Black and Calcium Carbonate on Curing Characteristics and Dynamic Mechanical.Properties of Natural Rubber. Journal of Methal Material and Mineral. 12(1): 51-57.

Dewantara, D, (2015), Kaolin Sebagai Bahan Pengisi Pada Pembuatan Kompon Karet Pengaruh Ukuran Dan Jumlah Terhadap Sifat Mekanik Fisik, Jurnal Dinamika Penelitian Industri, 26 (1) : 4148

Ellul, MD dan DR Hazelton (1998),Chemical Surface Treatments of Natural Rubber and EPDM Thermoplastic Elastomer: Effect on Friction and Adhession Rubber Chem. Technol. RT Vanderbilt Company Inc, Ohio.

Eqwaikhide, EE. Akporhonor dan F.E. Okieimen (2008), "The Characterization of Carbonised Coconut Fibre as Fillers in Natural Rubber Formulation" Trends Applied Research.

http://www.disperindagJabar.go.id/diaks es $17 / 10 / 2008$

Fachry, R, Tuti, S, Boby, A dan Dwi AK, (2012), Pengaruh penambahan filler kaolin terhadap elastisitas dan kekerasan produk souvenir dari karet alam, Pekanbaru, Dalam Seminar Nasional Teknologi Oleo dan Petrokimia Indonesia, Pekanbaru, Universitas.

Fang, Q., Song, B., Tee, T., Sin, L. T., Hui, D., \& Bee, S. (2014). Investigation of dynamic characteristics of nano-size calcium carbonate added in natural rubber vulcanizate. Composites: Part B, 60, 561-567

Herminiwati dan Arum Y (2010), Penggunaan PCC Sebagai Filler Untuk Sol Karet Sepatu Olahraga, Majalah Kulit Karet Plastik, Vol. (26)1: 25-32

Indiah, RD dan Hemirniwati, (2014), Lateks Karet Alam untuk Sol Sepatu Metode Pembuatan, sifat mekanik dan Morfologi. Majalah Kulit, Karet dan Plastik, Vol. 30 (2): 61-70 
Jeong, SH., JH, Kim and CJ, Hong (2013), Selecting Optimal Interlining with a Neutral network, Textile Research Journal, 70 (11) PP 1005-1010)

Luftinor, (2017), Penggunaan lateks alam cair untuk pembuatan kain interlining, Jurnal Dinamika penelitian Industri, 28 (2) : 7686

Maged S. Sobhy, D.E. Nashar, E.L. and Nabila (2008), Cure Characteristics and Physicomechanical.Properties of Calcium Carbonate Reinforcement Rubber Composites, Journal of Egypt. J. Sol, 26 (2) : 241-257.

Mishra, S and Shimpi NG (2005), Mechanical and flame retarding properties of styrene -butadiene rubber filled with nano $\mathrm{CaCO}_{3}$ as a filler and linseed oil as an extender, Jurnal of Apple Polimer Sci 98 (6) 2563-2571

Morton, M, (2008), Introduction of Rubber Technologi, New York, Reinhold Publishing Corporation

Mustafa, NS (2012), Effect of Kaolin on the Mechanicsal Properties of Polypropilena Composite Material, Diayala Journal of Engeneering Sciencis, Vol. 05 (02) : $162-178$

Nuraya, ASS, Baharin, A, Azura, AR, dan Hakim, MH (2012), Reinforcement of prevulcanised natural rubber latex film by bananastem powder and comparison with silica and calcium carbonat, Jurnal of Rubber Research, 15 (2): 124-140

Polmanteer, KE and Lentz, C. W., (2008) Effect of Silica Structure on Properties and Crosslink Density, Rubber Chem Technol, 20 (5) :795-809.

Poompradub, S., Luthikaviboon, T., Linpoo, S., Rojanathanes, R., \& Prasassarakich, P. (2011). Improving oxidation stability and mechanical properties of natural rubber vulcanizates filled with calcium carbonate modified by gallic acid. Polymer Bulletin, 66 (7), 965-977.

Ridla, B., Trisye, U dan Indra, PS., (2008), Kaolin Sebagai Sumber $\mathrm{SiO}_{2}$ Untuk Pembuatan Katalis $\mathrm{Ni} / \mathrm{SiO}_{2}$, Makara Sains, Vol. 12 (1), 37-43

Richard, S (2009), Latex Technology, London, John Willey and Sons Inc

Sasidharan, KK, Joseph, R, Palaty, S and Pillai, PV (2007), Effect of vulcanization time and storage on the stability and physical properties of sulfur prevulcanized natural rubber latex, Journal of Applied Polimer science, 97 (1): 1804-1812
Sitorus, IMS, Yudha, W dan Indra, S, (2013), Pengaruh Penambahan Alkalonamida Terhadap Karakteristik Pematangan dan kekerasan Vulkanisat karet alam Berpengisi Kaolin, Jurnal Teknik Kimia USU, 4(1): 38-46

William JH, (2008), "Pyrolysis of Latex Glove in the Presence of Y-Zeolite", Journal ofwaste management 29 (4) : 797-803.

Stagg, R (2007), Latex Technology. John Wiley and Sons Inc.

Sulam, A.L, (2008), Teknologi Pembuatan Benang dan Kain, Jakarta, Departemen Pendidikan Nasional,

Suparman, Surdia, NM dan Budiarti, (2009), Teknologi Penyempurnaan Tekstil, Bandung, Institut Teknologi Tekstil,

William JH, (2008), "Pyrolysis of Latex Glove in the Presence of Y-Zeolite", Journal ofwaste management 29 (4) : 797-803.

Yudha, W,. Sitorus, IMS, Indra S, (2013), Pengaruh penambahan alkalonamida terhadap sifat uji Tarik vulkanisat karet alam berpengisi kaolin, Jurnal Teknik Kimia USU, Vol. 2, No. 4. 